\title{
Den jødiske tøsedreng \\ Eksegese over Daniel Boyarin: Unheroic Conduct. The Rise of Heterosexuality and the Invention of the Jewish Man (1997)
}

\author{
Af Thomas Burø og
}

JaKob Egholm FeldT

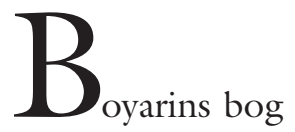

Unheroic Conduct. The Rise of Heterosexuality and the Invention of the Jewish Man er et omfangsrigt advokatur for queer-perspektivet som et utopisk håb for en verden uden fallocentrisme og kolonialisme. Den jødiske mand, som både antisemitismen og zionismen foragter, fungerer som et lysende eksempel på en ufrivillig queer, en negativ stereotyp, som påtages og påkaldes som en frigørende modsætning. Boyarins tænkning hjemsøges af den frigørende modsætnings modsætningsfyldthed i spørgsmål om, hvordan man frakaster sig maskuliniteten, kønnet og navigerer mellem at være sig selv (singulær) og høre til (partikulær). I dette essay lader vi vores tanker flyde med Boyarins bestræbelser på særlige nedslag i konflikten mellem det singulære og det partikulære; mellem jødedom og zionisme. Undervejs håber vi på at udfolde og indvinkle aspekter af queer-teoriens muligheder og umuligheder. 


\section{APORIA}

Boyarins tænkning hjemsøges af en uløst konflikt, en aporia. På den ene side er der et ønske om en multikulturel verden med plads til en reformeret jødedom, der i sin balancering af traditional jødisk praksis og modernitet formår at positionere sig som en feministisk, queer og ikke-koloniserende kultur (Boyarin 1997: xxiii). På den anden side er der et ønske om frisættelse fra kønslighed (Boyarin 1997: 19). Identitet er det fælles referencepunkt. Mens tilhøret til et fællesskab betyder at identificere sig med det og dets begrænsninger, betyder frisættelsen fra kønslighed en opløsning af identitet og altså hermed af tilhør til fællesskab. Denne aporia er grundlæggende for Boyarins etiske projekt, der tager form som et formiddabelt stykke queer teori, hvilket han udøver i mere end én forstand. Først og fremmest definerer Boyarin queer teori, som den påstand, at der intet naturligt er ved seksualitet (Boyarin 1997: 14). Yderligere er det den påstand, at køn på samme måde som seksualitet, er historiske konstruktioner (Boyarin 1997: 14). Men Boyarin teoretiserer også det punkt, hvor det jødiske og queer falder sammen (Boyarin et al 2003: 1), hvilket er, hvor Boyarins tænkning vover mest og dermed også er mest original.

Michel Foucault identificerede reguleringen og reproduktionen af den arbejdende krop som 1800-tallets europxiske kapitalistiske nationalstaters motiverende interesse bag skabelsen af heteroseksualitet, som en meningsfuld seksual kategori, hvis fundamentale formål er at sikre den fortsatte strøm af arbejdskraft (Foucault 1994: 143ff). Selvom Boyarins arbejde er inspirireret af Foucaults forståelse af køn og seksualitet, så finder vi et andet fokus hos Boyarin. Til forskel fra Foucault er Boyarins blik rettet mod jødisk konstruktion af seksualitet og køn. Men Boyarin påstår ironisk, at opfindelsen af heteroseksualitet er en begivenhed, der løber sideløbende med assimilerede centraleuropæiske jøders opfindelse af den jødiske mand (Boyarin 1997: 28).
Opfindelsen af heteroseksualitet, defineret som 'produktionen af en befolkning af menneskelige hanner, der (angiveligt) under ingen omstandigheder er i stand til at blive seksuelt ophidset af en person af eget køn' (Boyarin 1997: 14), indebærer ligeledes opfindelsen af homoseksualitet. Normal seksualitet er ikke blot nydelsesfuld, men tillige patriotisk, fordi den har som formål at producere mere arbejdskraft. Når den enkeltes identifikation med heteroseksualitet indebærer, at den enkelte opfatter nogle seksualle handlinger som normale og andre som unormale, da må opfindelsen af heteroseksualitet forstås som skabelsen af en etik. Konsekvensen af denne queer teoretiske påstand er, at den enkeltes identitet er den størrelse der på en og samme tid skaber og begrænser den enkelte. Judith Butler har dybsindigt kaldt den enkeltes forhold til egen identitet for en lidenskabelig tilknytning til egen undertrykkelse, en tilknytning baseret på det simple forhold, at det er denne selvundertrykkelse, der garanterer social meningsfuldhed og overlevelse (Butler 1997: 7). Det er først, når Du anerkender Mig, at Jeg bliver til Mig Selv. Hvis Jeg fremforer heteroseksualitet og Du anerkender dette som heteroseksualitet, så er Jeg heteroseksuel. Herved er jeg blevet socialt meningsfuld: min væren passer ind i de kategorier vores kultur stiller os til rådighed.

Boyarins aporia kan derfor bedst betegnes som en nødvendig ambivalens, fordi to etiske værdier står i et forhold af fortsat, uløst forhandling: den enkeltes frisættelse fra kønnets og seksualitetens begrænsende og dominerende kategorier overfor den enkeltes nødvendige bekræftelse af identitet og tilhør til et fællesskab, der netop indebærer en bekræftelse af kønslige og seksuelle kategorier.

\section{SINGULÆR}

Hos Alain Badiou finder vi et begreb for det singulære, som dét der ikke repræsenteres i en given situation, men som ikke desto 
mindre eksisterer i den (Badiou 2005: 99). At det singulære ikke repræsenteres i situationen betyder, at det ikke er kendbart, at det er hinsides meningsfuldhed og meningsløshed. Det singulære bliver kendbart i det øjeblik, det gøres til et element i situationen ved at det underkastes de rammer for kendbarhed, som rumsterer i situationens lokale bestemmelse af viden og sandhed. En sådan kategori kunne være identitetsmarkørerne 'homoseksuel', ‘jøde' eller 'mand', der først og fremmest får deres meningsfuldhed ved at referere til en mængde af kvaliteter, der kendetegner frellesskaberne 'homoseksuelle', 'jøder' 'mænd'. Man kunne her vende Badiou en smule på hovedet ved at påstå, at det singulære altid optræeder som en repræsentation, som en partikulær instans af en generel identitet. Dette udgør ikke Boyarins singularitet. Det repræsenterer Boyarin meningsfuldt ved at transformere hans singularitet til en partikulær instans af en generel identitet. Denne transformation af det singulære er altid en voldelig, epistemologisk reduktion, hvor nogle elementer ekskluderes til fordel for at fastholde andre træk, der i deres sammenføjning skaber et, med Badiou in mente, telleligt set. Den generelle identitet er selvsagt fuldstændig afhængig af denne optælling af elementer for at kunne fremstå som en fuldstændig størrelse. Problemet er blot, at det herved bliver til en abstraktion, som ingen egentlig inkarnerer. Det singulære udgøres netop af en række kvaliteter, hvis sammenføjning er unik og som derfor ikke kan generaliseres. Mellem det singulære og det partikulære kan man derfor lokalisere en zone, hvor det ikke er muligt at skelne det singulære liv fra dets væren som partikulær instans. Denne uskelnelighed udgør sammenføjningspunktet for Boyarins etiske problemstilling, fordi det forbinder det singulære livs forfølgelse af frihed, selvbestemmelse og selvskabelse med dets eksistentielle behov for at være at indgå i et fællesskab, der aldrig fuldt ud anerkender det singulære livs fuldstændig unikke væren.
Boyarin forsøger at skrive det singulære i sit værk. Mest tydeligt i sin afsluttende lidenskabelige behandling af Boyarins helt Bertha Pappenheim. Her fortælles historien om et liv, der på baggrund af den nødvendige ambivalens har formået at forhandle sig frem til en identitet, hvor ortodoks jødedom ikke var uforenelig med militant feminisme og homoseksuelt begær (Boyarin 1997: 312ff).

\section{UNIVERSEL}

Hvis Bertha Pappenheim derfor er Boyarins forsøg på at skrive det singulære, så udgøres Boyarins universalie af en noget anden figur. Det etiske projekt fungerer i kontrast til en bestemt form for kropslig væren, som fortrinsvis bliver udøvet af mandlige kroppe og som bærer en række bestemte kvaliteter. Maskulinitet er i Boyarins perspektiv fallisk (Boyarin 1997: Iff). For at forstå maskulinitet som fallisk er man nødt at skelne mellem det maskuline kønsorgan, som ikke er en fallos, og dets symbolske og metaforiske representation, som er fallos (Boyarin 1997: 9). At tænke maskulinitet som fallisk muliggøres af en proces, hvor egenskaber ved det mandlige kønsorgan overføres til hele den væren, som det blot er en del af. Med andre ord er det penis' evne til at erigere, ekspandere og penetrere, der ved denne begrebslige overførsel bliver gjort til egenskaber ved maskulin væren. White har kaldt denne bevægelse, hvor en del af en helhed gøres til en general kvalitet ved helheden, for en 'synekdotisk' (White 1973: 35-6). Fallisk maskulinitet er en trope, men en trope, der med Thomas' ord skal forstås 'seksuelt specifikt og metaforisk generelt' (Thomas 2002: 76), og tilmed en trope, der har kraft til at beskrive, hvorledes maskulinitet manifesterer sig i verden. I Pronger genfinder man denne trope i navngivelsen af maskulinitet som 'fallisk ekspansiv/analt kontraktiv'(Pronger 1998: 7lff). Fallisk ekspansion betegner maskulinitetens behov for at udfylde rum, 
for at penetrere, og i sidste ende, erobre andres rum og territorie. Anal kontraktion betegner forsegling og beskyttelse af eget rum og territorie mod andres invasioner. Denne toledede trope drager tydelige associationer til krig og det militære. Med Boyarins narrativ kan vi tilføje det koloniserende. Vi påstår, at den synekdotiske trope fallisk ekspansion/anal kontraktion fungerer som en trope ikke blot i Boyarin's narrativ, men $i$ en bredere forstand som en tankefigur fuldt ud integreret i vor kulturs maskulinitetstænkning, uanset om man forholder sig positivt eller negativt til den. Som en trope tjener den til at forme mulighederne for at udsige det maskuline ved netop at udstikke rammerne for det maskulines meningsfuldhed (White 1985: 2). Det er denne trope, der danner fundamentet for at kunne tænke maskulinitet som intimt forbundet med udøvelsen af magt og dominans.

Det interessante er nu, at Boyarin ikke forsøger at fremskrive et positivt billede af den jødiske mand for derved at opsætte et mandeideal, der kan tjene som den falliske maskulinitets Anden. Med Badiou er det muligt at skelne mellem mangfoldighed og mangfoldighed af mangfoldighed: en mangfoldighed er en mængde, hvor alle elementer er variationer over det samme. En mangfoldighed af mangfoldighed opstår, når der kan lokaliseres et element, hvis væren-anden ikke blot er en variation af det samme, men en egentlig Anden; en radikal forskellighed (Badiou 2005: 142ff). Boyarins etiske projekt er ikke drevet i retning af at tænke det maskuline i mangfoldighedstermer, forstået som muligheden for at tænke både falliske og ikke-falliske maskuliniteter der er grundlæggende forskellige fra hinanden - altså som en mangfoldighed af mangfoldigheder. Boyarin er en-dimensionalist i det omfang, at hans tænkning abonnerer på den fallisk ekspansive/analt kontraktive trope, som det maskulines sandhed. Maskulinitet er i sine forskellige fremtoninger blot vaiationer af det Samme. Som konsekvens heraf, bliver at nagte at vare en mand, et led i Boyarins etiske projekt, hvis man derved forstår 'mand' som maskulin (Boyarin 1997: 123). At fremskrive en væren, hvor en mandlig krop ikke forsøger at være maskulin på en ikke-fallisk måde, men slet og ret ikke-maskulin fordi maskulin betyder fallisk, og som derfor ikke søger at konkurrere med andre maskulinitetsformer om at opnå hegemoni. At fremskrive og hylde den 'jødiske tøsedreng' som et positivt ideal for udlevelsen af sin væren betyder derfor at 'fjerne fallos og efterlade penis' (Boyarin 1997: 11). Når Boyarin således positionerer sit alternativ i kontrast til fallisk maskulinitet er effekten dobbel: på den ene side bekræfter Boyarin denne maskulinitetsform som et universalie; på den anden side opsættes herved muligheden for at tænke dette universalie som en konkret forankret installation, hvis selvfølgelighed ikke er mere selvfølgelig, end at der kan finde forandring sted. Med Silvermans ord er fallisk maskulinitet en 'dominerende fiktion' (Silverman 1992: 15ff). At den er dominerende betyder, at dens fiktive fortællen det maskuline som fallisk accepteres i den sociale, kulturelle kontekst som fakta. Boyarins projekt er her ambitøst, fordi dets yderste grænse ikke er reformeringen af det maskuline, men revolutioneringen af vores værensfremførsel. Det er for Boyarin et spørgsmål om at erstatte én dominerende fiktion med en anden, hvorfor vi kan stille spørgsmålet, om der er et hierarki indlejret i det etiske projekt? Tjener den positive fremskrivning af denne jødiske tøsedreng først og fremmest til at reformere jødedommen som en komponent i en identitetspolitik, og kun sekundxrt som en del af en større bevægelse, hvor målet er den enkeltes frisættelse fra kønnet?

\section{MASKULIN DOMINANS}

Begrebet om fallisk maskulinitet er tæet forbundet med begrebet om maskulin dominans. Maskulin dominans, der også går under navnet patriarkat, er en tilstand, hvor 
magtrelationer og distributioner af privilegier og mangler er blevet institutionaliseret i det politiske, økonomiske, sociale og kulturelle system. Det forbindende led mellem fallisk maskulinitet og maskulin dominans er fallocentrisme, hvilket kan defineres positivt som agtelse for fallos, som agtelse for maskulin magtudøvelse (Bordo 1999: 87), og negativt som benægtelse af værdien af magtesløshed (Bersani 1987: 217). Nogle gange er en cigar blot en cigar, men det er når en cigar bliver til et symbol for penis, at den bliver til en fallos. Og hvis en cigar, $\mathrm{fx}$ røget af Winston Churchill eller Fidel Castro, kan blive til et agtet symbol for deres maskuliniserende udøvelse af magt, er det fallocentrisme. Denne definition er simpel. Langt mere radikal er den negative definition, hvor fallocentrisme bliver til agtelse af magt, der kun kan betragte magtesløshed som en afskyvækkende og patetisk tilstand. For maskulinitet er magtesløshed en tilstand af feminisering, fordi det feminine netop tænkes som den magtesløse modpol til den maskuline magt: det er kvinden, der handles på, der bestemmes over, der penetreres. At indtage en magtesløshedens position betyder for mænd en opløsning af maskulin identitet; for kvinder en bekræftelse af feminin identitet. Af begge parter værdisættes magtesløshed negativt, at være magtesløs er en ikke-atråværdig position. Hos Boyarin finder vi en utrættelig kritik af fallisk maskulinitet og af den fallocentriske agtelse for magt; tøsedrengen som mandeideal indebærer netop en værdisættelse af magtesløshed som etisk legitim og eftertragtelsesværdig. I den euro-amerikanske dominerende fiktion fortælles det maskuline som aggresivt, dominerende, hvilket Boyarins mandeideal er i skarp kontrast til.

For at kunne destillere dette ideal er Boyarin nødt til at konfrontere jødisk kulturs maskuline dominans. Den rabbinske jødiske kulturs maskuline eller måske rettere mandlige dominans er i Boyarins udlægning lige så udtalt som i den moderne europæiske kultur, Boyarin indtager et oppo- sitionelt forhold til. Den jødiske maskuline kultur er bare ikke fallisk, og derfor bliver den jødiske mand i relationen til den europæiske kulturs maskulinitet effeminiseret trods det, at Manden i jødedommen er den uomtvistelige autoritet/magt (Boyarin 1997: 151-185). Problemet refererer til Boyarins uforløste men konstruktive konflikt; det dobbelte begær efter både at være sig selv (singulær) og høre til (partikulær). Det forbliver uinteressant for Boyarin at opklare, hvad den jødiske mand er og var, men den jødisk/yiddishe mand bliver det ambivalente ideal i den måde han fremstår på i sin relation til den europæiske antisemitiske overmagt. En queer. Legitimeringen af dette ideal funderes i en genbeskrivelse af jødisk historie, der retter sig mod en potentiel fremtid, der skal kunne rumme Boyarins universelle solidaritet og partikulære kærlighed til jødedommen, dens historie og fællesskab. Denne historiske genbeskrivelse er et kald på kærlighed og samhørighed til og med et fællesskab, der samtidigt skal leve op til en etisk fordring om universel solidaritet. Jødisk historie skrives til at være historien om, hvordan et unikt, partikulært fællesskab kan bevares endda som en model til verden uden at dette fællesskab var konkretiseret og objektiviseret som politisk, territorial, koloniserende magt. Jødernes pagt med Gud om Eretz Israel er i Boyarins historie ikke en oprindelighedspagt. Det er en pagt, som indbefatter bevidstheden om at altid-allerede komme fra et andet sted. Jøderne indvandrede til Eretz Israel og udvandrede igen, og den vægtning er etisk. Den bringer påmindelser om middelalderfortolkeren Rashi (10401105), som udlagde pagten mellem Gud og Abraham således:

Skulle denne verdens nationer stille spørgsmål til gyldigheden af Israels ret til det hellige land ved at sige: 'I er røvere i det I har overløbet de syv folkeslags territorium'. Israel vil svare: 'Hele verden er Herrens. Han skabte den og gav den til hvem han havde lyst. Det 
var hans vilje at give den til dem, og det var hans vilje at tage den fra dem og give den til os (Rosenbaum \& Silberman 1985: 2-3).

Følgeslutningen er naturligvis, at Herren ligeledes kan tage landet fra jøderne igen, hvilket han også gjorde, og at det ikke kan føre til hævdelse af jødernes fysiske ejendomsforhold til landet. Rashis fortolkning var den mest udbredte i rabbinsk jødedom indtil zionismen, og Boyarin vælger sit fællesskab med den ikke-moderne rabbinske jødedom i en genklang af Martin Bubers (1878-1965) spirituelle nationalisme:

Der findes ikke en historisk ret i overordnet forstand: hvert kapitel i verdenshistorien, som bliver brugt til at legitimere en bestemt ret, kommer efter et andet kapitel, som kan støtte en anden ret. Derfor er det umuligt at kræve ret på baggrund af tid (Herzberg 1997: 463464).

Boyarin kræver retten til at høre til med sine egne i en påkaldelse af partikulariteten som skæbne men ikke uden krav til fællesskabet. Problemet for Boyarin bliver at tilhøre jødedommen som partikularitet ikke på nogen måde er det samme som queerness $i$ sig selv. Jødedommen og dens begreber om maskulinitet er kun queer og en dermed en potentiel budbringer om det, der kan komme i kraft af sin effeminisering gennem den moderne antisemitisme fra ca. $1800 \mathrm{og}$ frem. Boyarins krav til fællesskab er Bertha Pappenheim som ikon. En hybriditet mellem jødisk religiøsitet, socialisme og homoseksualitet, umiddelbart gensidigt ekskluderende partikulariteter som Boyarin forlanger anerkendt som netop håbet om singularitet og universel solidaritet. Igen placerer Boyarin sig med udgangspunkt i det uforløste, som er, at jødedommen er en udsøgt patriarkalsk kulturform, hvis Mand kun er en tøsedreng for det ikke-jødiske blik. Dette ville naturligvis være uacceptabelt for Boyarin at gøre som Herzl og acceptere antisemitismens konstruktion af jø- dedommen, hvorfor Boyarin finder sin inspiration i postkolonial litteratur hos fx Homi Bhabha og Franz Fanon. Den jødiske effeminiserede mand skabt af antisemitisme og den europæiske interne kolonisering af jøderne bliver en alternativitet og ikke en imitation. Derfor er jødedommens virkelige identitet ikke et spørgsmål, men den jødiske mands postkoloniale queerness er et potentiale. Tiden og historien er ikke en legitimitet men en etisk og erotisk kærlighedshistorie, som kan fungere som rum for det dobbelte begær mellem etik og erotik med spændingen intakt. Boyarin vælger at give fantasien til afmagten i en nærmest lacansk forstand (Hyldgaard 1998).

Kærlighedserklæringen til jødedommen hos Boyarin giver kun mening, hvis vi læser den med psykoanalytiske briller. I psykoanalysen er kærligheden ikke en forening men en erfaring af to mængder (Hyldgaard 2003: 132). Kærligheden bliver erfaringen af forskellighed - den anden bliver den Anden. Således altid uforløst og umulig vil foreningen med jødedommen være som alle andre ægte begærsrelationer. Jødedommen bliver aldrig omformet i Boyarins billede, men det er kun en tragisk historie for den, som forventede foreningen. Der er ingen hverken kynisk eller sentimental tale om jødedommen i Boyarins værk men et meget nærværende engagement med den Anden. Patriarkatet og den hårde fordømmelse af homoseksualitet i jødedommen består men hos Boyarin op i mod et krav om anerkendelse af Bertha Pappenheim som en helt, hvilket virker for opløsningen af den mandlige dominans' dogmatik, dvs. i det mindste for en mangfoldiggørelse.

\section{ZIONISMEN SOM IMITATION}

I Boyarins perspektiv er zionismen jødernes mest problematiske reaktion på moderne tankegang. Zionismen hævder at være en frihedskamp for jødernes partikularitet, dvs. for selve muligheden for at være jødisk og menneske på samme tid (Herzberg 1997). 
Det er en kamp mod antisemitismens billede af jøderne og i særdeleshed den jødiske mand som en bedragerisk, sanselig, svag og liminel karakter, der ikke passer ind i den europæiske orden. Antisemitismen har et permanent fokus på jødernes subversive potentiale for den rene og ordentlige europæiske kultur. Den jødiske mand er en kimær i den radikale antisemitisme og en kvinde $\mathrm{i}$ den mere latente antisemitisme (Langmuir 1990). I begge tilfælde er der tale om variationer af det samme. Både kvinden og kimæren er farlige, sanselige, mystiske og liminelle, der er blot tale om forskellige grader af det diabolske. Således er jødernes queerness i den moderne tankegang farlig på flere abstraktionsniveauer: den jødiske mands svaghed/magtesløshed/ kvindelighed er farlig og gør ham til en nærmest monstrøs fjende, fordi han er en modstander uden for den fallocentriske kategori og det gør ham uanerkendbar. På et højere abstraktionsniveau bliver jøderne som fællesskab en anomali i nationalismens Europa. De bliver til folket uden et land og dermed et historisk-strukturelt problem for Europas opdeling i en naturlig orden udgjort af nationer med tilhørende territorier. Niveauerne er absolut sammenhængende og jøderne vandrer over og mellem grænserne for moderne ontologiske kategorier både i kønslige, historiske og politiske termer, selvom det er den samme grænse som overskrides nemlig grænsen mellem det naturlige og det sociale. Hvad er zionismens egentlige mål, hvis man som Boyarin studerer dens identitetspolitik? Det fremtræder som et i konteksten oxymoronisk ønske: den normale jøde (Feldt 2007).

Zionismen søgte i slutningen af 1800tallet og begyndelsen af 1900-tallet at skabe en jødisk fallisk maskulinitet gennem en modernisering af jødedommen, dvs. en ny moderne jødisk bildung, og samtidigt i sammenhæng dermed at erobre et fysisk territorium til jøderne. Dermed kunne jøderne normaliseres, anerkendes, på alle niveauer som tilhørende både mændenes og folkeslagenes fællesskab (Biale 1986; Berkowitz 1997). Dette folkeslagenes fællesskab er både naturligt og socialt, hvorimod verden uden for 'Vesten' er 'hybrid' (Bhabha 1994; Greenblatt 1991; Said 1978). Zionismens mål er at udrydde jødernes hybriditet, og det kan kun ske gennem europæisk anerkendelse af, at zionisternes problem med jøderne er det samme som antisemitternes nemlig jødernes manglende moderne bildung og territorium. Som Boyarin ironisk bemærker ønskede Herzl 'Phallustine' og ikke bare 'Palestine' (Boyarin 1997: 222). Zionisternes ønske om den normale jøde indbefattede udrensningen af den magtesløse jødiske mand og som følge deraf rabbinsk jødisk religion. Den rabbinske magtesløshed overfor Herrens vilje skulle oversættes til, at historiens og naturens vilje kunne ske fyldest gennem en tilbagevenden til Eretz Israel. Som den zionistiske essayist Ahad Ha'am beskrev det, skulle den jødiske sjæl (jøderne) forenes med den jødiske krop (Landet). Jødernes ville få deres bibelske potens tilbage, historiens telos ville opfyldes, og jødisk religions magtesløshed overfor Herren kunne påskønnes for dens rolle i bevarelsen af sjælen. Efter foreningen af krop og sjæl ville den mission være overstået, og jøderne kunne påbegynde et naturligt liv (Herzberg 1997). Ahad Ha'am tilhørte den absolut mest apologetiske gren af zionismen overfor jødedommen, hvorimod Herzl, Nordau og mange andre ledere var decideret fjendtlige. Boyarin hæfter sig ikke ved grader af 'det jødiske problem', men ved, at de zionistiske ledere var besatte af behovet for anerkendelse. Zionistiske sportsklubber skød op over hele Europa, som skulle bygge jødiske mænd op fysisk og opdrage dem til sund kappestrid. Jødiske helte blev skrevet frem som store stærke falliske krigermænd, og Herzl selv blev ofte portrætteret som en ny Moses i figur som en antik græsk atlet. Kampen mod effeminiseringen af de jødiske mænd skulle stå i sport, i kulturen og i politikken. En central metafor for zionismens kulturkamp blev 
duellen. Anerkendelsen også som fjende kunne i zionisternes øjne kun ske gennem de herskende begreber, så jøder blev opfordret til at rejse sig op for deres jødiskhed, til at duellere og til at $\mathrm{d} \varnothing$, hvis det gjaldt. Det er bedre at dø med xre end at overleve i skam, er moralen i Herzl's skuespil 'Das Neue Ghetto', ligesom det senere zionistiske diktum: 'Det er godt at dø for vores land' (Boyarin 1997: 271-312; Zerubavel 1995). Zionisterne drog ud for at kolonisere Palæstina og der skabe en imitation af Europa så fantastisk at selv europæerne måtte beundre den (Herzl 2007). I koloniseringen af Palæstina og opbygningen af den falliske jødiske mand, ville jødernes anerkendelse bestå, men er så ikke jødedommen i sin zionistiske variant bare deutschtum under navnet Israel?

Boyarins svar på det er bekræftende. Zionismen er den gode indfodtes politik, den komplette imitation af overmagten i et begær efter anerkendelse, som politisk blev praktiseret perfekt. Anerkendelsen kom fordi zionisterne ikke forsøgte at blive tyske men ligesom, hvorimod tysk-jødiske patrioter aldrig formåede at blive rigtigt tyske, ej heller selv om de konverterede til kristendommen. Læren er, at det ikke er mandigt at løbe fra sig selv. Herzl havde erkendt dette, så selv da han i sine sorteste timer forestillede sig jødisk massekonvertering til kristendommen, ville han selv ikke konvertere. Han ville være den sidste jøde, kaptajnen som gik ned med skuden, hvilket viser, at Herzl forstod betydningen af den europæiske fallocentrisme - en betydning som Herzl følte før, at han havde noget konkret begreb om, hvad der politisk skulle gøres (Herzl 1960: 7). I Boyarins perspektiv er zionismen følgelig en falliterklæring og jødedommens moralske monster, fordi zionisterne overtager alle de fallocentristiske voldsformer fra Europa inkl. kolonialismen og opløser dermed jødedommens utopiske potentiale. Zionismen som jødisk partikulært fællesskab lever hverken op til at være jødisk eller universelt solidarisk.

\section{FRISÆTTELSE FRA KØNNET}

Deleuze og Guattari har lanceret begrebet om "flugtlinien" for at beskrive alle de bevægelser, hvormed noget undslipper eller forbliver umåleligt, eller med deres eget ord, usanseligt (Deleuze \& Guattari 1999: 216). I flugtlinien er indlejret et kritisk potentiale for forandring, fordi det netop er mangfoldigheden af flugtlinier der i deres optik gør, at hverken nationalstatens kontrol eller kapitalismens domæne bliver totalt: der vil altid være noget, der forsvinder, der siver, lækker eller stikker af. Det er i de mikroskopiske bevægelser at forandringen og modstandspunkterne begynder (Deleuze \& Guattari 1999: 216). Det er det singulære individ, der i forhandlingerne omkring den konkrete udforming af sit køn som partikulær instans af en generel kønsidentitet, skaber forskydninger og forandringer. Hos Boyarin er det Pappenheim og, selvfølgelig, Boyarin selv.

Vi har lokaliseret Boyarins apori til at være det punkt, hvor hans tænkning ikke kan finde ud af, om det ser det singulæres frisættelse fra partikularitet som den etiske målsætning eller om det er den kritiske reformering af den generelle identitet (og i sidste ende ophævelsen af universel maskulinitet), der skal gælde som drivende værdi. Vi kan nu blive mere præcise. Boyarins problem er netop uskelnelighed, fordi, som Badiou påpeger, selv for de revolutionære, som har satset deres liv på fremkomsten af noget nyt, er det passende at være kendbar (Badiou 2005: 294). Kendbar, forstår vi som anerkendbar i en social sammenhæng. Den singularitet, der insisterer på at være konsekvent usanselig og ukendbar bliver til Ingen; den ophører ganske enkelt med at være. Er den enkeltes frisættelse fra kønnet ikke sådan en bliven-usanselig? Deleuze \& Guattari er klar over, at flugtlinien altid er i fare for at ende i (selv)destruktion, hvorved de antyder, at en tilstand af usanselighed er en tilstand af fare og fællesskabsløshed (Deleuze \& Guattari 1999: 299). Ligeledes er usanseligheden, ukønnetheden, også begærsløsheden. Livet uden forskellighed. 


\section{LITTERATUR}

- Badiou, Alain (2005): Being and Event, Continnum

- Berkowitz, Michael (1997): Western Jewry and the Zionist Project 1914-1933, Cambridge University Press

- Bersani, Leo (1987): Is the Rectum a Grave? In AIDS: Cultural Analysis/Cultural Activism. October Vol. 43, pp. 197-222

- Bhabha, Homi (1994): The Location of Culture, Routledge

- Biale, David (1986): Power and Powerlessness in Jewish History, Schocken Books

- Bordo, Susan (1999): The Male Body - a New Look at Men in Private and in Public, Farrar, Straus and Giroux

- Boyarin, Daniel (1997): Unheroic Conduct - The

Rise of Heterosexuality and the Invention of the

Jewish Man, University of California Press

- Boyarin, Daniel, Itzkovitz, Daniel \& Pellegrini, Ann (ed.) (2003): Queer Theory and the Jewish Question, Colombia University Press

- Butler, Judith (1997): The Psychic Power of Life, Stanford University Press

- Connell, RW (1995): Masculinities, University of California Press

- Deleuze, Gilles \& Guattari, Félix (1999): A

Thousand Plateaus - Capitalism and Schizophrenia, The Athlone Press

- Feldt, Jakob (2007): The Israeli Memory Struggle. History and Identity in the Age of Globalization, University of Southern Denmark Press

- Foucault, Michel (1994): Viljen til viden - Seksualitetens historie 1, DET lille FORLAG

- Greenblatt, Steven (1991): Marvelous Possessions. The Wonders of the New World, University of Chicago Press

- Herzberg, Arthur (1997): The Zionist Idea, The Jewish Publication Society

- Herzl, Theodor (1960): The Complete Diaries of Theodor Herzl, Herzl

- Herzl, Theodor (2007): Altneuland, Filiquarian Classics

- Hyldgaard, Kirsten (1998): Fantasien til afmagten, Museum Tusculanum

- Hyldgaard, Kirsten (2003): Det utidige subjekt, Roskilde universitetsforlag

- Langmuir, Gavin (1990): Towards a Definition of Antisemitism, University of California Press

- Latour, Bruno (2006): Vi har aldrig veret moder$n e$, Hans Reitzel

- Pronger, Brian (1998): On Your Knees: Carnal
Knowledge, Masculine Dissolution, Doing Feminism in Digby, Tom (ed.) Men Doing Feminism, Routledge, pp. 69-80

- Rosenbaum \& Silberman (1985): Chumash with Rashi's Comments, Phillip Feldheim

- Said, Edward (1978): Orientalism, Penguin

- Silverman, Kaja (1992): Male Subjectivity at the Margins, Routledge

- Thomas, Calvin (2002): Re-enfleshing the Bright Boys in Gardiner, Judith Keegan (ed.) Masculinity Studies and Feminist Theory: New Directions', Colombia University Press

- White, Hayden (1973): Metahistory, The John Hopkins University Press

- White, Hayden (1985): The Tropics of Discourse Essays in Cultural Criticism, The John Hopkins University Press

- Zerubavel, Yael (1995): Recovered Roots, Collective Memory and the Making of Israeli National Tradition, University of Chicago Press

\section{ENGLISH ABSTRACT}

This essay deliberates on Daniel Boyarins book Unheroic Conduct. The Rise of Heterosexuality and the Invention of the Jewish Man (1997). It seeks to unfold Boyarins reading of the development of modern Jewish masculinity as a vivid piece of queer theory. Boyarin considers the Jewish Man to be an ideal for a future without phallocentrisme and colonialism. We discuss this suggestion in relation to the concepts of the singular and the particular in the philosophy of Alain Badiou in particular and related philosophical perspectives in Deleuze \& Guattari and Bruno Latour.

Jakob Feldt, ph.d.

Adjunkt, Center for Mellemøststudier,

Syddansk Universitet

Svalehøjvej 5, 5800 Nyborg

feldt@hist.sdu.dk

$60927027 / 62201511$

Thomas Martin Møller Burø, cand.mag

Flensborggade $33 \mathrm{l}$ tv, $1669 \mathrm{KBH} \mathrm{V}$

Tommythecat@ofir.dk

$20720667 / 33257648$ 